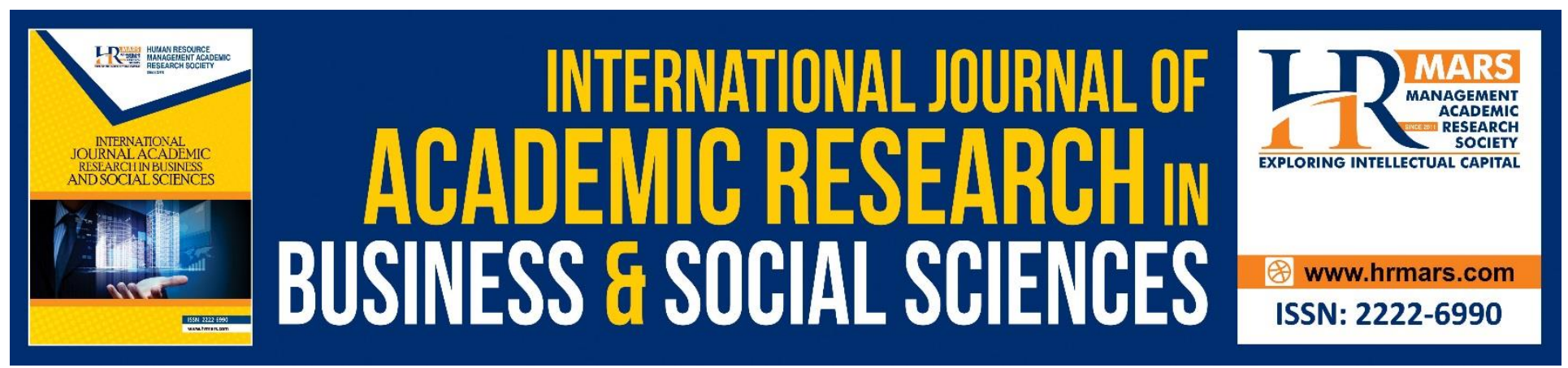

\title{
Gender Preference and Child Labour in Indonesia
}

\section{Dayang Haszelinna binti Abang Ali, Reza Arabsheibani}

To Link this Article: http://dx.doi.org/10.6007/IJARBSS/v8-i12/5320

DOI: $10.6007 /$ IJARBSS/v8-i12/5320

Received: 11 Nov 2018, Revised: 07 Dec 2018, Accepted: 20 Dec 2018

Published Online: 27 Dec 2018

In-Text Citation: (Ali \& Arabsheibani, 2018)

To Cite this Article: Ali, D. H. binti A., \& Arabsheibani, R. (2018). Gender Preference and Child Labour in Indonesia. International Journal of Academic Research in Business and Social Sciences, 8(12), 1742-1759.

\section{Copyright: (c) 2018 The Author(s)}

Published by Human Resource Management Academic Research Society (www.hrmars.com)

This article is published under the Creative Commons Attribution (CC BY 4.0) license. Anyone may reproduce, distribute, translate and create derivative works of this article (for both commercial and non-commercial purposes), subject to full attribution to the original publication and authors. The full terms of this license may be seen

at: http://creativecommons.org/licences/by/4.0/legalcode

Vol. 8, No. 12, 2018, Pg. 1742 - 1759

Full Terms \& Conditions of access and use can be found at http://hrmars.com/index.php/pages/detail/publication-ethics 


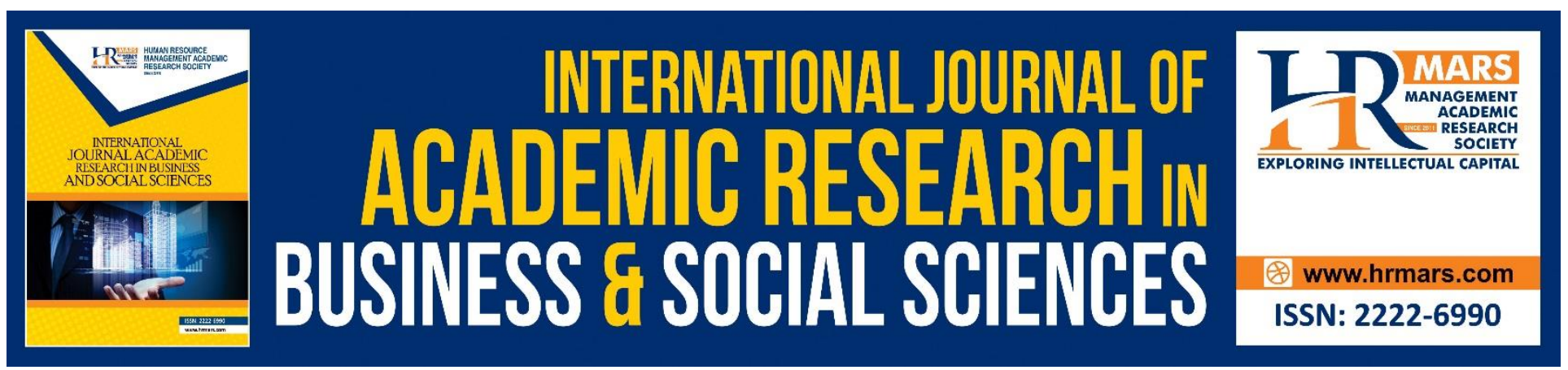

\title{
Gender Preference and Child Labour in Indonesia
}

\author{
Dayang Haszelinna binti Abang Ali ${ }^{1}$, Reza Arabsheibani ${ }^{2}$ \\ ${ }^{1}$ Centre for Policy Research and International Studies, Universiti Sains Malaysia \\ ${ }^{2}$ Department of International Relations, London School of Economics and Political Science \\ Email: dyghaszelinna@usm.my
}

\begin{abstract}
This study examines the gender differentials in the time allocation in children activity, and whether son preference explained the differences. The time allocation is separated to hours spent on schooling, hours spent on house work and hours devoted to market work. The tested hypothesis is that the prevalence of son preference indicates that girls have less leisure time compared to the boys. The data are drawn from Indonesia Family Life Survey (IFLS) wave 4 in 2007, implementing the Tobit model on the variables such as children's hours of work, child's household's and community's characteristics. The findings suggest that the difference between the average numbers of hours worked of the boys and the girls have a statistically differential effect on working and doing housework. In addition, girls aged 5-14 years spend more hours on schooling and doing housework, however boys aged 15-17 years more likely to spend their time on working.
\end{abstract}

Keywords: Gender Preference, Child Labour, Indonesia, IFLS4, Hours of Work, Tobit Model

\section{Introduction}

Gender preferences for children are widely discussed around the world. The considerable attention that has been devoted to this issue is parental gender differences which can contribute to discriminatory practices against children. Consequently, these practices may have unfavourable social and demographic consequences. In particular, having a particular gender preference can lead to gender-selective abortions, which generate an imbalance in the gender ratio of the population. This problem will cause a delay in the age of marriage, or an increase in the number of people who never marry (Hank and Kohler, 2000). According to Fuse (2010), the problem of gender preferences also results in gender differentials in infant and child mortality. In society where adults favour boys than girls, female child mortality rates exceed male child mortality. In addition, gender preference also brings about gender bias in the household in the provision of basic care, such as nutrition, immunization, medical treatment, and in time allocation. Thus, this may affect the health and wellbeing of children (Fuse, 2010). A major discussion regarding gender differences are degree of preference for sons, which is widely manifested in East and South Asia, including China, South Korea and India. 
In Indonesia, gender differences among children still especially occur in the school enrolment. The reasons behind this condition are differential opportunity costs of schooling for both genders, and gender differences in traits, gender specialization in jobs and gender discrimination in the labour market. For example, school-age girls are generally more valuable in child care of their siblings and doing household chores, the opportunity cost in terms of home production is greater for the girls than boys. However, in terms of market wages, the opportunity cost of schooling may be greater for the male compared to the female. In particular, the gap in enrolment rates between the boys and girls in Indonesia starts revealing itself around secondary school age, which is 12 years, and increases gradually through age of 23 years (Deolalikar, 1993). Moreover, adult women face substantial discrimination, where $93 \%$ of managers of formal enterprises are male and over $98 \%$ of village heads are male (Kevane \& Levine, 2003).

\section{Literature Review}

The effects of son preference by parents on child labour, schooling, bequests and welfare have been studied by Kumar (2011) by developing a model with bilateral altruism between parents and children. His study distinguishes between two cases, a pure son-preference case and pureearning function bias towards males. In the son-preference case, both boys and girls receive equal amount of schooling when parents can give bequests. However, boys receive more schooling and work less than girls when parents cannot give bequests. This condition is also observed in the case of earning function bias, when parents cannot give bequests. In addition, boys will receive more or less schooling and work more or less than girls when parents cannot give bequests in case of earning function bias. Alternatively, in the son-preference case, time allocated to leisure for boys is higher than girls. Since data on bequests and reverse transfers are difficult to obtain in Bangladesh, this study only focussed on the time allocated to leisure by the boys and girls. Son preference leads to girls having a lesser amount of leisure than boys. In other words, girls should work more than boys. Therefore, using worked hours as the dependent variable, this study implemented the Tobit model on Bangladesh Multiple Indicator Cluster Survey (MICS) for 2005-2006 on children with the age of 514 years. The hypothesis of this study says that if there is a son preference; boys have more time for leisure compared to girls. The results show that, on average, boys worked 3.35 hours per week compared to 4.65 hours in the case of girls, which is significant at $1 \%$ level. The result supports the hypothesis, where boys work less hours than girls, which gives them more time for leisure compared to girls. Therefore, this result confirms that son preference is an important factor in explaining gender differential in child labour, especially in rural Bangladesh.

A large gender gap in housework among girls compared to boys is associated with the son preference in India. This has been studied by Lin \& Adsera (2012), where son preference is measured by a mother's ideal proportion of sons among her children. To examine the relationship between son preference and the level of children's housework, this study uses the Ordinary Least Square (OLS) and random-effect models of hours of work of all children using the National Family Health Survey of India (NFHS-3) of 2005-2006. This chapter adopted a broader definition of child labour, which also includes housework, in assessing children's welfare which is influenced by different types of activities (see Canagarajah \& Coulombe, 1997; Bhalotra \& Heady, 2000; Khanam, 2006, Webbink, 2010). Studies by Edmonds (2006) and Basu et al (2009) also include household chores in discussing the incidence of 
child labour. With the specification of son preference, family size, religion and caste, the results show an increase in girls' burden of household chores of around 2.5 hours per week compared to boys. In high-caste families, girls do 5.96 hours of housework, which is 2.3 hours higher than boys, but do less housework than the other families, where girls do an average of 7.51 hours of household work. In addition, an increase in the gender gap of housework is not significant among Muslim children. In terms of the rank of siblings, older children do more household chores than younger ones. However, in families of three and four children, the presence of a sister is associated with fewer hours of housework. Next, the study measures son preference with fertility intention to have another child when there is an equal number of boys and girls, which is driven by a desire for sons than daughters. On average, boys do 2.76 hours of housework if their mother does not intend to have a third child, and the period decreases to 2.63 hours if their mother does. However, the hours of doing housework for girls' increases from 4.1 to 5.1 if the mother plans more children.

Gallego \& Sepulveda (2007) address the issue of gender differences in educational attainment and work activities among children in Columbia. In particular, they investigate why poor girls have more educational attainment compared to boys, and as families relax their budget constraints, how it affects the variability of gender gap in education and work activities. Their study follows a basic theory framework of child labour of Baland \& Robinson (2000) and Horowitz \& Wang (2004), where they explain the entire gender gap in education by differences in wages and subjective ability towards schooling with perfect capital markets and without budget constraints. The empirical analysis utilizes data from Familiasen Accion, which is a social program that has been implemented in Colombia, where subsidies are given to poor rural families' conditional upon school attendance of children aged 7 and above. By including the wage that the child earns in the labour market, the gender gap in schooling is reduced by $43 \%$, which represents $40 \%$ of the raw gap. Furthermore, with the subjective desire towards schooling, (based on the questions "how much education the child would like to get" and "how much she would be able to get, if she has the chance") this element decreases the gap by $55 \%, 50 \%$ of raw gap. These two effects show a direct substitutability between work and schooling, excluding domestic work.

Since girls in low-income households are at risk from such bias in household resource allocation, Koolwal (2007) investigates whether household fertility preference for sons and the mistreatment of girls can be reduced if they can generate income for the household. Son preference is defined by the household's average reported ideal number of sons relative to ideal number of children. This study uses the Nepal Living Standards Survey (NLSS) of 1995 and 1996, implementing OLS and Instrumental Variables (IV) estimates at both the household and community (ward) level. The IV estimates show that an increase in daily earnings of girls decreases demand for sons by 0.04 for children in the age of 10-15 years. For children with the age of 16-18 years, the reduction is 0.016 , and the effect is much stronger for younger children. At the ward level, the girl's expected wage reduces the demand for sons by 0.05 for children with the age of 10-15 years; however, there is no significant effect on older children. The education of adult women shows a strong negative impact, however, men's schooling has no significant impact on the demand for sons. In addition, a household with large plot sizes of agricultural land has a higher demand for sons. Households in rural areas and access to piped drinking water negatively related to the demand for sons. She concludes that the 
INTERNATIONAL JOURNAL OF ACADEMIC RESEARCH IN BUSINESS AND SOCIAL SCIENCES

Vol. 8, No. 12, Dec, 2018, E-ISSN: 2222-6990 C 2018 HRMARS

upsurge in expected wages of girls of Indian Rupees, Rs. 20-25 (equivalent to USD 0.33-0.41) per day decreases the demand for a son.

\section{Methods}

\section{Theoretical Modelling}

Based on two-sided altruism of Baland \& Robinson (2000), there are two periods in the model, $t=1,2$ and parents are treated as a single decision-making and consumption unit. The economy consists of a large number of households and firms and each household consists of parents and two children. Parents and children live for both periods. Parents work and supply labour in elastically and parent is assumed to have an efficiency units of labour in each period. Firms ${ }^{1}$ are owned by other type of agents, who live for two periods and do not have children. In the first period, children are endowed with one unit of time, which can be spent as work, schooling and leisure. Children incur disutility from both schooling and work, and parents face a direct trade-off between schooling and child labour (Baland \& Robinson, 2000; Horowitz \& Wang, 2004). Schooling in the first period raises the labour endowment of children in terms of earnings in the next period.

Let labour supplied by boys and girls be defined by $l^{m}$ and $l^{f}$, respectively (Kumar, 2011). Human capital acquired by $i$ th child of next period are assumed to depend on the time spent on schooling, $s^{i}$. The human capital function, $h^{i}\left(s^{i}\right)$ for $i=m, f$ is assumed to be strictly increasing, homogeneous of degree one and concave function of $s^{i}$. In addition, assume that $h^{i}(0)>0$ (Kumar, 2011 ; p. 5). Both children and parents are altruistic. Parental utility depends on the parents' own consumption and utility levels of children. Though parents care about both of their children, they may prefer boys over girls. Therefore, the parental utility function is:

$$
W^{p}=U\left(c_{p}^{1}\right)+U\left(c_{p}^{2}\right)+\delta^{m} W^{m}+\delta^{f} W^{f}
$$

Where, $U()^{2}$ is the period utility function, $c_{p}^{t}$, the consumption by parents in both periods, parameters $0<\delta^{i}<1$ for $i=m, f$, measure the degree of altruism, and $W^{m}$ and $W^{f}$ are utility functions of the boys and girls, respectively, which are defined as:

$$
\begin{aligned}
& W^{m}=U\left(c^{m}\right)+V\left(1-l^{m}-s^{m}\right)+\gamma W^{p} \\
& W^{f}=U\left(c^{f}\right)+V\left(1-l^{f}-s^{f}\right)+\gamma W^{p}
\end{aligned}
$$

Where $V\left(1-l^{i}-s^{i}\right)$ is an increasing and concave function of leisure $\left(1-l^{i}-s^{i}\right) . \gamma$ is the degree of altruism by children towards their parents. Combining (1), (2) and (3) the expression for $W^{i}$ for $i=p, m, f$ is:

${ }^{1}$ Firms are assumed to produce goods using labour (which is hired in a competitive labour market) and have linear technology (Kumar, 2011).Therefore, wages per efficiency unit of labour are constant, which are normalized to 1 .

${ }^{2} U($ ) is a twice continuously differentiable, strictly increasing, and concave function of consumption (Kumar, 2011). 


$$
W^{p}=\frac{\sum_{t=1}^{2} U\left(c_{t}^{p}\right)+\sum_{i=m, f} \delta^{i}\left[U\left(c^{i}\right)+V\left(1-l^{i}-s^{i}\right)\right]}{1-\gamma\left(\delta^{m}+\delta^{f}\right)}
$$

$W^{m}$

$=\frac{\left(1-\gamma \delta^{f}\right)\left[U\left(c^{m}\right)+V\left(1-l^{m}-s^{m}\right)\right]+\gamma\left[\sum_{t=1}^{2} U\left(c_{t}^{p}\right)+\delta^{f}\left[U\left(c^{f}\right)+V\left(1-l^{f}-s^{f}\right)\right]\right]}{1-\gamma\left(\delta^{m}+\delta^{f}\right)}$

$W^{f}$

$=\frac{\left(1-\gamma \delta^{m}\right)\left[U\left(c^{f}\right)+V\left(1-l^{f}-s^{f}\right)\right]+\gamma\left[\sum_{t=1}^{2} U\left(c_{t}^{p}\right)+\delta^{m}\left[U\left(c^{m}\right)+V\left(1-l^{m}-s^{m}\right)\right]\right]}{1-\gamma\left(\delta^{m}+\delta^{f}\right)}$

For well-defined utility functions to exist, a condition that parameter values of $1>\gamma\left(\delta^{m}+\delta^{f}\right)$ will be imposed. Parents choose their consumption for both periods including savings, child labour, time spent in schooling and bequests for both children. The rate of return on savings is normalized to one. Further, in the second period, parents give bequests, $b^{i} \geq 0$ for $i=m, f$ to their children. In return, children also give transfers, $\tau^{i} \geq 0 ; i=m, f$, to their parents in the second period of their lives. By letting $k$ be the savings in the first period, the budget constraints faced by both parents and children will be:

$$
\begin{aligned}
& c_{1}^{p}+k=A+l^{m}+l^{f} \\
& c_{2}^{p}+b^{m}+b^{f}=A+k+\tau^{m}+\tau^{f} \\
& c^{m}=b^{m}-\tau^{m}+h^{m}\left(s^{m}\right) \\
& c^{f}=b^{f}-\tau^{f}+h^{f}\left(s^{f}\right)
\end{aligned}
$$

The choice of $\tau^{i}$ is conditioned on all previous choices by parents, and parents consider the way where transfers are affected by their own choices in maximizing Equation (4). We can consequently solve for the equilibrium allocation of resources by solving for the optimal choice of $\tau^{i}$ conditional on $l_{i}, k$ and $b$. This satisfies the first-order condition:

$$
V^{\prime}\left(h^{i}\left(s^{i}\right)\right)+b^{i}-\tau^{i}=\gamma U^{\prime}\left(A-b^{i}+k+\tau^{i}\right)
$$

In making their initial choices, parents anticipate the effects on the transfer they get from their child. A positive transfer from child to parent is like a negative bequest. In our case, we focus on the transfer from parents to children.

\section{Parents to Children Transfer}

With the transfer from parents to children, $b^{i}>0, \tau^{i}=0$, for $i=m, f$, the parental optimization problem is: 
INTERNATIONAL JOURNAL OF ACADEMIC RESEARCH IN BUSINESS AND SOCIAL SCIENCES

Vol. 8, No. 12, Dec, 2018, E-ISSN: 2222-6990 @ 2018 HRMARS

$$
c_{1}^{p}, c_{2}^{p}, l^{m}, l^{f}, s^{m}, s^{f}, b^{m}, b^{f}, k \frac{\sum_{t=1}^{2} U\left(c_{t}^{p}\right)+\sum_{i=m, f} \delta^{i}\left[U\left(c^{i}\right)+V\left(1-l^{i}-s^{i}\right)\right]}{1-\gamma\left(\delta^{m}+\delta^{f}\right)}
$$

subject to the budget constraints of Equation (3) to (11). With the interior solution for child labour of $0<l^{m}, l^{f}<1$, the first-order conditions associated with the optimal choices, are:

$$
l^{i}: U_{c}\left(c_{1}^{p}\right)=-\delta^{i} V_{l}\left(1-l^{i}-s^{i}\right) \text {, for } i=m, f
$$

The left-hand side is the marginal benefit of child labour and the right-hand side is the marginal cost. In the first period, parental utility is increased by $U_{c}\left(c_{1}^{p}\right)$ by one additional unit of child labour; however, it decreases the utility enjoyed by the $i$ th child by $-\delta^{i} V_{l}\left(1-l^{i}-s^{i}\right)$.

$$
s^{i}: U_{c}\left(c^{i}\right) h_{s}^{i}\left(s^{i}\right)=-V_{s}\left(1-l^{i}-s^{i}\right), \text { if } s^{i}>0, \text { for } i=m, f
$$

Equation (11) defines the marginal cost of the time spent in schooling to its marginal benefits. The earnings of child increases in the next period as the schooling time is increased by $h_{s}^{i}\left(s^{i}\right)$. The utility enjoyed by the $i$ th child also reduces by $-\delta^{i} V_{s}\left(1-l^{i}-s^{i}\right)$. Equation (12) equates the marginal cost of time spent in schooling exceeds its marginal benefit, which is denoted by following equations:

$$
\begin{aligned}
& s^{i}: U_{c}\left(c^{i}\right) h_{s}^{i}\left(s^{i}\right)<-V_{s}\left(1-l^{i}-s^{i}\right), \text { if } s^{i}=0, \text { for } i=m, f \\
& b^{i}: U_{c}\left(c_{2}^{p}\right)=\delta^{i} U_{c}\left(c^{i}\right), \text { if } b^{i}>0, \text { for } i=m, f \\
& b^{i}: U_{c}\left(c_{2}^{p}\right)>\delta^{i} U_{c}\left(c^{i}\right), \text { if } b^{i}>0, \text { for } i=m, f \\
& k: U_{c}\left(c_{1}^{p}\right)=U_{c}\left(c_{2}^{p}\right) .
\end{aligned}
$$

The left-hand side of Equation (13) is the marginal cost of giving bequest to child, $i$, and the righthand side is the marginal benefit. Utility of parents is reduced by $U_{c}\left(c_{2}^{p}\right)$ with an additional unit of bequest in the second period. At the same time, the utility of parents is increased by $\delta^{i} U_{c}\left(c^{i}\right)$. Parents will not give any bequest to the $i$ th child if the marginal cost of bequest to the $i$ th child exceeds marginal benefit, which is shown by Equation (17). The marginal cost of savings ${ }^{3}$ is denoted by the left-hand side of Equation (18) with its marginal benefit (right-hand side). Income increases by one unit in the next period as savings increase by one unit, with the value of $U_{c}\left(c_{2}^{p}\right)$. Equation (12) implies that:

$$
\delta^{m} V_{l}\left(1-l^{m}-s^{m}\right)=\delta^{f} V_{l}\left(1-l^{f}-s^{f}\right) .
$$

\footnotetext{
${ }^{3}$ The marginal cost of savings is the loss in the utility by having to consume one unit less in the first period.
} 
INTERNATIONAL JOURNAL OF ACADEMIC RESEARCH IN BUSINESS AND SOCIAL SCIENCES

Vol. 8, No. 12, Dec, 2018, E-ISSN: $2222-6990$ @ 2018 HRMARS

Son preference $\left(\delta^{m}>\delta^{f}\right)$ leads to boys having higher amount of leisure than girls and $l^{m}+s^{m}>$ $l^{f}+s^{f}$, which is tested in the analysis. Both boys and girls have the same amount of leisure in the absence of son preference, which is, $l^{m}+s^{m}=l^{f}+s^{f}$.

\section{Data}

The data are drawn from the Indonesian Family Life Survey (IFLS4), a continuing longitudinal socioeconomic and health survey, which provides data on households and communities in Indonesia, covering $83 \%$ representatives of the Indonesian population living in 13 out of the 27 provinces in Indonesia.

The survey collects data on individual respondents, their families, their households, the communities in which they live, and the health and education facilities they use. In particular, the survey also provides detailed information on the employment activities and schooling of children with the age of 5-17 years. For children younger than 11 years, the child's mother, female guardian, or caretaker answered the questions. Children between the ages of 11 and 14 years were allowed to respond for themselves if they felt comfortable doing so. However, for children with the age of 15 years and above, they are interviewed individually. The allocation of time includes hours spent in employment activities, in school and do housework. In particular, the spent hours on employment activity includes hours spent on 'working' in the family farm, non-farm business as well as working for outsiders. In hypothesis testing, girls have less leisure than boys, instead of hours devoted on working, the hours spent doing household chores and hours spent in school also included, since working, do housework and attend school are considered as non-leisure activity.

The sample consists of 9,461 children with the age of 5-14 years with 4,843 boys and 4,612 girls. In addition, since this study covers children below 18 years, this paper also includes 2,502 children with the age of 15-17 years with 1,232 boys and 1,270 girls. Thus, in total, the sample consists of 11,963 children.

\section{Explanatory Variables}

Independent variables used in this chapter include child characteristics, household-specific characteristics and regional characteristics, which are based on the existing literature and are widely used. For child characteristics: gender, the child's age and age-squared are the variables used in the regression. A dummy variable of girls is included as this variable will be the reference for the hypothesis, which takes value 1 if child is a girl and 0 otherwise. In particular, a positive sign of coefficient showing that girls have more non-leisure's time allocation than boys, and vice versa. This indicates that girls have less leisure than boys which supports the hypothesis. As shown in the previous chapter, older children are more likely to go to work than younger children (Priyambada et al, 2005; Kamga, 2010; Rosati \& Rossi, 2007). The age-squared variable captures possible nonlinearity in the effect of age as the children get older. Hence, if the age-squared has negative effect, which means that as children get older, the effect of age is reduced (Ray \& Lancaster, 2003). There is evidence of parental altruism towards their own children. Therefore, the dummy variable of others (the relationship with the head of the household) is included to capture the differences in preferences in the household. The dummy variable takes a value of 0 if a child is a son and a daughter of the 
household head and 1for others. This variable is expected to have a positive association with housework, and negative association with doing house work and working.

Household characteristics include education level of father and mother. This variable may reflect their relative bargaining power in the household decision making. Previous literature has argued that fathers have a greater say on the decisions about their sons and mothers have a greater say on the decisions of their daughters. Further, both variables may have differential effects on children's time allocation (Parikh \& Sadoulet, 2005). The availability of father and mother at home is included as explanatory variables as the role of both adult men and women is different in the household. In most developing countries, women are found to work inside the home or as homemakers, and men are breadwinners and work outside the home. These gender differences in the activities may also get reflected in the division of labour among the boys and the girls. In particular, if the father does not stay at home, boys will take turns to be breadwinners to the family by working outside their home. Otherwise, if mother does not stay at home, the girls will take up her roles and responsibilities. Therefore, these variables are tested to examine whether it has a differential effect on the boys' and girls' child labour.

Other household characteristics which are included in the model are the household income, the household size, and the number of children aged below 5 in the household. IFLS data provides information on the individual earnings of each household member who is reported to be working in the survey week. Since paid child labour raises household income, children's income is not taken into account in computing the total of household income to avoid aggregation bias. A higher household income is expected to have a negative impact on working and doing housework (Grootaert, 1998; Cockburn, 2001; Rogers \& Swinnerton, 2003). In contrast, increase in household income is estimated to positively relate to hours of schooling. The household size replicates the available pool of family labour and affects the incentives for the family either to put the children to work or not. This variable is expected to have a negative effect on working (Bhalotra \& Heady, 2001; Guarcello et al, 2004; Jeong, 2005; Togunde \& Richardson, 2006). In addition, the presence of children under 5 in the household needs child care that might increase the responsibility of mother which reduces her availability for other activities. Therefore, this is likely to be the factor that increases the demand for working children (Carvalho-Filho, 2008). According to Rosati \& Rossi (2002), the presence of preschool-age children reduces the enrolment probability of children, and has the opposite effect on the hours spent on housework and working.

In Indonesia, over 40 million people lack access to improved water source and this condition remains a serious challenge to the provincial government level, especially in slums and rural areas ${ }^{4}$. Therefore, fetching water remains the most important household chore in rural areas. To reduce the hours spent on working and doing household chores, the presence of clean drinking water source is greatly needed (Guarcello et al., 2004). Hence, the dummy variable for the households that receive piped water takes value of 1 , and 0 otherwise. To capture the effect of the cultural and social norms on child labour, the dummy variable of religion is included. Since $88.2 \%$ of the people in Indonesia are Muslims, this variable takes the value of 1 if the religion is Muslim, and 0 otherwise (see also

\footnotetext{
${ }^{4}$ The World Bank (2014). "Indonesia: World Bank Group President Flags Sanitation As Key Priority for Ending Poverty". Retrieved January 8, 2014 from http://www.worldbank.org/en/news/pressrelease/2014/04/11/indonesia-world-bank-group-president-flags-sanitation-as-key-priority-for-ending-poverty
} 
Canagarajah \& Coulombe, 1997; Krolikowski, 2007). Apart from the child and household characteristics, dummies for the region are also included in the model, where Indonesia is divided into five islands ${ }^{5}$ : Sumatera, Java, Lesser Sunda Islands, Kalimantan, and Sulawesi. Sulawesi is treated as the base.

\section{Methodology}

To examine the relative significance of the two types of gender bias, the following regression model is estimated. A Tobit model is considered for child labour supply in order to take into account the nature of our dependent variable of total hours of work, which the distribution is censored from below at zero due to non-participation in either the market or domestic work. Since the hypothesis tested is boys have more leisure time compared to girls in prevalence of son preference, thus the total hours of work includes hours spent at school, work and do housework. The analysis estimates for boys and girls, separately for children aged 5-14 years and $15-17$ years. According to Basilio (2009) and Kumar (2011), hours worked could be described as a response variable that includes the value zero with positive probability but is a continuous variable over strictly positive value. Therefore, following Basilio (2009), the Tobit model is written as:

$$
H_{i}=\alpha_{i j}+\beta_{i j} X_{i j}+\varepsilon_{i j} \quad \text { for } i=m, f \text { and } j=1,2
$$

where, $H$ is the vector of the number of hours worked in a week by child $i$ in group $j$ (two groups: 514 years and $15-17$ years), $\alpha$ is the estimated constant term, $X$,represent gender explanatory variables and $\beta$, the associated coefficient vector. In addition, $\varepsilon$ is the error term which is assumed to be normally distributed. Theoretical model suggests explanatory variables will have different effects for boys and girls so we estimate the function, separately by gender. Moreover, Equation (20) is estimated separately for children aged 5-14 and 15-17 years to investigate the differential effects of the explanatory variables based on age of the children since the time spent in working and schooling are different between two groups of age (which is found in Chapter 4, where younger children tend to go to school more than older children). It is inevitable that children may not participate in any activity, or their parents did not report the hours spent to work, school and housework. In addition, children may be 'idle' or do not do anything, which consequently, the dependent variables have a zero value. Since there are reported number of hours is zero the data are censored at zero, thus a censored regression of tobit model is estimated to estimate Equation (20) which expresses level of $y$ in terms of an underlying latent variable, $y^{*}$ :

$$
\begin{aligned}
y_{i}^{*}= & \beta_{0}+\beta_{1} x X_{i}+\varepsilon_{i} \\
y_{i} & =\left(\begin{array}{ll}
\beta_{0}+\beta_{1} x X_{i}+\varepsilon_{i} & \text { if } y_{i}^{*}>0 \\
0 & \text { if } y_{i}^{*} \leq 0
\end{array}\right.
\end{aligned}
$$

The tobit model is used for this analysis because the data includes zero values of dependent variable, and the observed zero values are not due to the decision of individual households, but due to

${ }^{5}$ IFLS only covers five islands during the survey. Therefore, instead of seven islands in Indonesia, only five are dealt with in this chapter. The two islands that are not covered during survey are Maluku and New Guinea. 
censoring. Equation (21) indicates that the observed number of hours is positive continuous for positive number of hours desired. Therefore, since the non-negative values of hours worked, dependent variable $Y_{i}$ is censored at zero. This model is nonlinear and thus, it is estimated using maximum likelihood estimation techniques. The likelihood function for the tobit model takes the form

$$
\ln L=\sum_{0} \ln \left[1-\emptyset\left(\frac{x_{i} \beta_{i}}{\sigma}\right)\right]+\sum_{+} \ln \left[\frac{1}{\sigma} \varphi\left(\frac{Y_{i}-x_{i} \beta_{i}}{\sigma}\right)\right]
$$

where, " 0 " implies the zero observations (hours worked $Y_{i}$ is zero) in the sample and "+" implies the positive observations (hours worked $Y_{i}$ is positive). $\emptyset($.$) and \varphi($.$) indicate standard cumulative$ distribution function and standard normal probability density function, respectively. Estimated coefficients from the tobit model is not directly interpreted. It is a bit more complex than interpreting estimated coefficients from the OLS model. Specifically, the estimated coefficients represent the marginal effect of $x$ on $y$. Thus, the estimated coefficients from the tobit model represent: $\frac{\partial E\left[y_{i}^{*} \mid x\right]}{\partial x_{i}}=$ $\beta$ and thus correspond to the marginal effect of $x$ on the latent variable $y^{*}$ not to be observed variable $y$. Sometimes $y^{*}$ is what is of interest but usually it is not. What is really wanted is the marginal effect of $x$ on $y$. Therefore, the expected value of $y$ conditional on $y$ being greater than zero, which is given by:

$E\left[y_{i} \mid y_{i}>0\right]=\beta_{0}+\beta_{1} X_{i}+\sigma\left[\frac{\emptyset\left(\beta_{0}+\beta_{1} X_{i}\right) / \sigma}{\Phi\left(\beta_{0}+\beta_{1} X_{i}\right) / \sigma}\right]$

Thus, the desired marginal effects are then the derivative of Equation (23) with respect to $x$.

\section{Results and Discussions}

\section{Marginal Effects of Individual and Household Characteristics on Hours Spent on Schooling per Week by Gender}

Table 1 presents marginal effects of child, household and community characteristics on time spent on children's time allocation. The results suggest that being a girl increases the time devoted to schooling activities by 0.47 hour per week for children aged 5-14 years and 1.22 hours per week for children aged 15-17 years with respect to males. This suggests that girls are more likely to be in school compared to boys for both age groups. The higher increase in schooling hours is observed when fathers stay at home. In particular, the effect is larger for children aged 15-17 years, where the hours devoted to school increased by 3.7 hours per week for boys and 4.8 hours per week for girls. The levels of education of parents also increase the hours spent on schooling. The effects are greater by father's education compared to mother's education, for boys compared to girls and for older children compared to younger children. A small and significant effect is given by the household income for both groups.

Being a non-biological child of the head of the household have less time devoted to school and the same results are also given by the presence of child under 5 years in the household. Both these results are only significant for children aged 5-14 years, but not significant for children 15-17 
INTERNATIONAL JOURNAL OF ACADEMIC RESEARCH IN BUSINESS AND SOCIAL SCIENCES

Vol. 8, No. 12, Dec, 2018, E-ISSN: 2222-6990 ¿ 2018 HRMARS

years. In addition, household size and being a Muslim did not show any significant effects on the hours spent on schooling. In terms of region, children residing in Lesser Sunda Islands are more likely to allocate their time on schooling compared to children in Sumatera. Similarly, children residing in Java and Sulawesi are more likely to devote their time on schooling as opposed to their counterparts in Sumatera.

Table 1: Tobit (Marginal Effects) of Hours Spent of Children on Schooling

\begin{tabular}{|c|c|c|c|c|c|c|}
\hline \multirow{2}{*}{$\begin{array}{c}\text { Explanatory } \\
\text { Variables }\end{array}$} & \multicolumn{3}{|c|}{ Children Aged 5-14 years } & \multicolumn{3}{|c|}{ Children Aged 15-17 years } \\
\hline & All & Boys & Girls & All & Boys & Girls \\
\hline Girls & $\begin{array}{c}0.4726 * * \\
(0.1839)\end{array}$ & & & $1.2241^{* *}$ & & \\
\hline \multirow[t]{2}{*}{ Age } & $12.7157^{*}$ & $12.7631 *$ & $12.7012 *$ & $-2.7758^{*}$ & $-1.2451^{*}$ & $-2.2629 * * *$ \\
\hline & $(0.2658)$ & $(0.3650)$ & $(0.3876)$ & $(1.9810)$ & $(0.4030)$ & $(1.6060)$ \\
\hline \multirow[t]{2}{*}{ Age Squared } & $-0.5736^{*}$ & $-0.5736^{*}$ & $-0.5753^{*}$ & 0.7509 & 0.0046 & $1.4615^{* * *}$ \\
\hline & $(0.0138)$ & (0.0189) & $(0.0201)$ & $(0.5972)$ & $(0.8269)$ & $(0.8637)$ \\
\hline \multirow[t]{2}{*}{ Others } & $-0.1413^{*}$ & $-0.3721^{*}$ & $-0.0770^{*}$ & 0.2048 & 0.2424 & 0.2641 \\
\hline & $(0.0219)$ & $(0.1055)$ & $(0.0314)$ & $(0.6365)$ & $(0.8947)$ & $(0.8912)$ \\
\hline \multirow[t]{2}{*}{ Father-Stay } & $1.8778^{*}$ & $2.1393^{*}$ & $2.5576^{* *}$ & $3.0050 * *$ & $3.7495^{*}$ & $4.8120 *$ \\
\hline & $(0.4394)$ & $(0.6137)$ & $(0.6283)$ & $(1.2840)$ & $(1.9050)$ & (1.7699) \\
\hline \multirow[t]{2}{*}{ Mother-Stay } & -0.2952 & -0.6645 & 0.7969 & -2.3573 & -2.8892 & -0.6636 \\
\hline & $(0.6759)$ & $(0.9207)$ & $(0.9917)$ & (1.5289) & (1.9195) & $(2.5767)$ \\
\hline Father's Education & $0.2098^{*}$ & $0.2163^{*}$ & $0.2013^{*}$ & $0.1968^{*}$ & $0.4697^{*}$ & $0.1525^{*}$ \\
\hline Mother's Education & $(0.0332)$ & $(0.0449)$ & $(0.0493)$ & (0.1031) & $(0.1421)$ & $(0.0153)$ \\
\hline Household Income & $0.1293^{*}$ & $0.1367^{*}$ & $0.1210 * *$ & $0.1780^{*}$ & $0.1990^{*}$ & $0.1632 * *$ \\
\hline \multirow[t]{2}{*}{ Piped } & $(0.0326)$ & $(0.0439)$ & $(0.0483)$ & $(0.0947)$ & $(0.1139)$ & $(0.1397)$ \\
\hline & $0.0005^{*}$ & $0.0002^{*}$ & $0.0002^{*}$ & $0.0002 *$ & $0.0003^{*}$ & $0.0001 *$ \\
\hline \multirow[t]{2}{*}{ Household Size } & $(0.0001)$ & $(0.0001)$ & $(0.0001)$ & $(0.0001)$ & $(0.0001)$ & $(0.0001)$ \\
\hline & $0.0310^{*}$ & $0.3160^{*}$ & $0.2824^{*}$ & 0.5156 & 1.1625 & 0.0651 \\
\hline \multirow[t]{2}{*}{ Muslim } & $(0.0102)$ & $(0.0307)$ & (0.0323) & $(0.6951)$ & (1.0078) & $(0.9707)$ \\
\hline & -0.0356 & 0.0178 & -0.0932 & 0.0585 & 0.0328 & 0.0360 \\
\hline Child (Aged below & $(0.0334)$ & $(0.0457)$ & $(0.0488)$ & $(0.0984)$ & $(0.1377)$ & $(0.1515)$ \\
\hline 5) & -0.5033 & -0.5372 & -0.4539 & 1.2651 & 1.0257 & 1.7021 \\
\hline \multirow[t]{2}{*}{ Java } & (0.3209) & $(0.4364)$ & $(0.4720)$ & $(0.8247)$ & (1.1873) & (1.1527) \\
\hline & $-0.3388 * *$ & $-0.5188^{* *}$ & $-0.1685^{*}$ & 0.5122 & 0.7040 & 0.4347 \\
\hline \multirow{2}{*}{$\begin{array}{l}\text { Lesser Sunda } \\
\text { Islands }\end{array}$} & $(0.1536)$ & $(0.2137)$ & $(0.0221)$ & (0.5588) & $(0.7757)$ & $(0.8002)$ \\
\hline & $-1.8562^{*}$ & $-1.8271^{*}$ & $-1.9069^{*}$ & $-2.4561^{*}$ & $-1.8592 * * *$ & $-3.1940^{*}$ \\
\hline \multirow[t]{2}{*}{ Kalimantan } & $(0.2374)$ & $(0.3227)$ & $(0.3505)$ & $(0.7749)$ & $(1.0628)$ & (1.1244) \\
\hline & $2.6409 *$ & $2.5337^{*}$ & $2.7428^{*}$ & $4.8777^{*}$ & $5.3220^{*}$ & $4.7289^{*}$ \\
\hline \multirow[t]{5}{*}{ Sulawesi } & $(0.3605)$ & $(0.4817)$ & $(0.5363)$ & (0.9284) & (1.3089) & (1.1327) \\
\hline & 0.6037 & 0.3916 & 0.7744 & 1.4756 & 1.9188 & -0.2026 \\
\hline & $(0.4500)$ & $(0.6372)$ & (0.6348) & $(1.6340)$ & $(2.2973)$ & $(2.2223)$ \\
\hline & $-2.0668^{*}$ & $-2.3384^{*}$ & $-1.7882^{*}$ & $-2.8129 * *$ & $-3.5787 * *$ & -1.3709 \\
\hline & $(0.4116)$ & $(0.5612)$ & $(0.6029)$ & $(1.2565)$ & $(1.8256)$ & $(1.9162)$ \\
\hline Pseudo $\mathrm{R}^{2}$ & 0.0596 & 0.0622 & 0.0573 & 0.0067 & 0.0105 & 0.0056 \\
\hline Number of & 9461 & 4843 & 4618 & 2502 & 1232 & 1270 \\
\hline Observations & & & & & & \\
\hline Log-likelihood & -32249.520 & -16342.813 & -15898.637 & -7001.114 & -3481.804 & -3503.284 \\
\hline
\end{tabular}

Notes: $*, * *, * * *$ statistically significance at $1 \%, 5 \%$ and $10 \%$. 
INTERNATIONAL JOURNAL OF ACADEMIC RESEARCH IN BUSINESS AND SOCIAL SCIENCES

Vol. 8, No. 12, Dec, 2018, E-ISSN: 2222-6990 @ 2018 HRMARS

\section{Marginal Effects of Individual and Household Characteristics on Hours Spent on Housework per Week by Gender}

Table 2 presents marginal effects of different covariates on time spent on house work and gender is shown to be an important determinant of time spent on doing household chores. The results suggest that being a girl increases the time spent on house work by 1.26 hours per week compared to boys. Increase in age also increases the hours devoted to house work by 1.09 hours for girls and 0.89 hours per week for boys. In addition, a non-biological child spent more time doing housework as opposed to a biological child, and the effect is larger for girls relative to boys.

Both parents who stay in the household increase the hours spent on housework, which is significant for girls, but not for boys. The given effect is larger by fathers compared to mothers. Household income and having piped water in the household are negatively associated with the hours devoted to housework, which is also found to be significant only for girls. Girls and boys spend 0.04 hour per week and 0.03 hour per week respectively less on house work if there is an additional household member. This may be due the chores being divided equally among household members, which contributes to the less hours spent on house work among the available household members. Being a Muslim increases the hours work by 0.27 hours per week for boys and 0.33 hours per week for girls. The presence of children aged less than 5 years increases the hours devoted on house work by 0.23 hour per week for boys. The effects are larger for girls, where their hours increase by 0.79 hour per week since girls are more responsible for child care compared to boys. The region variables show significant effects, where children in all listed islands spend fewer hours on house work compared to their counterparts in Sumatera. 
INTERNATIONAL JOURNAL OF ACADEMIC RESEARCH IN BUSINESS AND SOCIAL SCIENCES Vol. 8, No. 12, Dec, 2018, E-ISSN: 2222-6990 @ 2018 HRMARS

Table 2: Tobit (Marginal Effects) of Hours Spent of Children on Housework

\begin{tabular}{|c|c|c|c|}
\hline \multirow[t]{2}{*}{ Explanatory Variables } & \multicolumn{3}{|c|}{ Children Aged 5-14 years } \\
\hline & All & Boys & Girls \\
\hline Girls & $\begin{array}{l}1.2616^{*} \\
(0.0510)\end{array}$ & - & - \\
\hline Age & $\begin{array}{l}0.9920^{*} \\
(0.0824)\end{array}$ & $\begin{array}{l}0.8914 * \\
(0.1167)\end{array}$ & $\begin{array}{l}1.0925^{*} \\
(0.1242)\end{array}$ \\
\hline Age Squared & $\begin{array}{l}-0.0304^{*} \\
(0.0042)\end{array}$ & $\begin{array}{l}-0.0286^{*} \\
(0.0059)\end{array}$ & $\begin{array}{l}-0.0309 * \\
(0.0063)\end{array}$ \\
\hline Others & $\begin{array}{c}0.0057^{* *} \\
(0.0025)\end{array}$ & $\begin{array}{l}0.0126 * \\
(0.0075)\end{array}$ & $\begin{array}{l}0.0146^{*} \\
(0.0010)\end{array}$ \\
\hline Father-Stay & $\begin{array}{l}0.3073^{*} \\
(0.1145)\end{array}$ & $\begin{array}{c}0.0549 \\
(0.1594)\end{array}$ & $\begin{array}{l}0.5584^{*} \\
(0.1746)\end{array}$ \\
\hline Mother-Stay & $\begin{array}{c}0.2953^{* * *} \\
(0.1724)\end{array}$ & $\begin{array}{c}0.3478 \\
(0.2267)\end{array}$ & $\begin{array}{c}0.2510 * * \\
(0.1277)\end{array}$ \\
\hline Father's Education & $\begin{array}{c}-0.0351^{*} \\
(0.0100)\end{array}$ & $\begin{array}{l}-0.0209 \\
(0.0137)\end{array}$ & $\begin{array}{l}-0.0503^{*} \\
(0.0155)\end{array}$ \\
\hline Mother's Education & $\begin{array}{l}-0.0085 \\
(0.0098)\end{array}$ & $\begin{array}{l}-0.0212 \\
(0.0135)\end{array}$ & $\begin{array}{c}0.0052 \\
(0.0147)\end{array}$ \\
\hline Household Income & $\begin{array}{c}-0.0001 * * * \\
(0.0001)\end{array}$ & $\begin{array}{c}0.0004 \\
(0.0005)\end{array}$ & $\begin{array}{l}-0.0001^{*} \\
(0.00002)\end{array}$ \\
\hline Piped & $\begin{array}{c}-0.1769 * \\
(0.0661)\end{array}$ & $\begin{array}{r}-0.0633 \\
(0.0940)\end{array}$ & $\begin{array}{c}-0.3070 * \\
(0.0983)\end{array}$ \\
\hline Household Size & $\begin{array}{l}-0.0298 * \\
(0.0104)\end{array}$ & $\begin{array}{l}-0.0413^{*} \\
(0.0139)\end{array}$ & $\begin{array}{l}-0.0257^{*} \\
(0.0165)\end{array}$ \\
\hline Muslim & $\begin{array}{c}0.0313 \\
(0.1039)\end{array}$ & $\begin{array}{c}0.2733^{* * *} \\
(0.1472)\end{array}$ & $\begin{array}{c}0.3306 * * \\
(0.1521)\end{array}$ \\
\hline Child (Aged below 5) & $\begin{array}{l}0.1998^{*} \\
(0.0488)\end{array}$ & $\begin{array}{l}0.2254^{*} \\
(0.0716)\end{array}$ & $\begin{array}{l}0.7925^{*} \\
(0.0704)\end{array}$ \\
\hline Jawa & $\begin{array}{l}-0.8995^{*} \\
(0.0688)\end{array}$ & $\begin{array}{c}-0.8332 * \\
(0.0927)\end{array}$ & $\begin{array}{l}-0.9993^{*} \\
(0.1072)\end{array}$ \\
\hline Lesser Sunda Islands & $\begin{array}{c}-0.2495^{* *} \\
(0.0985)\end{array}$ & $\begin{array}{c}-0.4538^{*} \\
(0.1292)\end{array}$ & $\begin{array}{l}-0.0338 \\
(0.1597)\end{array}$ \\
\hline Kalimantan & $\begin{array}{l}-0.8484^{*} \\
(0.1116)\end{array}$ & $\begin{array}{l}-1.0307^{*} \\
(0.1548)\end{array}$ & $\begin{array}{l}-0.7337^{*} \\
(0.1754)\end{array}$ \\
\hline Sulawesi & $\begin{array}{l}-0.6815^{*} \\
(0.1176)\end{array}$ & $\begin{array}{l}-0.7101^{*} \\
(0.1636)\end{array}$ & $\begin{array}{l}-0.6763^{*} \\
(0.1779)\end{array}$ \\
\hline $\begin{array}{c}\text { Pseudo } R^{2} \\
\text { Number of Observations } \\
\text { Log-likelihood }\end{array}$ & $\begin{array}{c}0.0630 \\
9461 \\
-14962.006\end{array}$ & $\begin{array}{c}0.0467 \\
4843 \\
-6037.7031\end{array}$ & $\begin{array}{c}0.0564 \\
4618 \\
-8886.875\end{array}$ \\
\hline
\end{tabular}

Notes: $*, * *, * * *$ statistically significance at $1 \%, 5 \%$ and $10 \%$.

\section{Marginal Effects of Individual and Household Characteristics on Hours Spent on Working per Week by Gender}

Table 3 shows marginal effects of independent variables on total hours spent in the labour force, and again the gender variable shows that being a girl decreases the time spent in the labour market by 1.13 hours per week and -1.77 hours per week for children aged 5-14 years and children aged 15-17 years, respectively. The effect of child's age on the hours spent in the labour market is significant for children aged 5-14 years, where the effects are larger for girls compared to boys. 
INTERNATIONAL JOURNAL OF ACADEMIC RESEARCH IN BUSINESS AND SOCIAL SCIENCES

Vol. 8, No. 12, Dec, 2018, E-ISSN: 2222-6990 @ 2018 HRMARS

Having fathers who stay at home largely decreases the hours among children aged 15-17 years, which is significant for girls. In particular, girls spend 7.71 hours per week if fathers stay at home. In contrast, boys spend 4.14 hours per week less if mothers stay at home. The years of education of both fathers and mothers, and household income significantly reduce the hours spent on market work. The large effects are observed among boys as opposed to girls. In addition, having piped water in the household decreases the boys' hours spent in the labour market by 1.84 hours per week. This significant and large effect is observed among children aged 15-17 years. Children aged 514 years, who are Muslims spend 1.20 hours per week compared to non-Muslim. Furthermore, the presence of child aged under 5 years in the household significantly increases girls aged 5-14 years' hours of work by 0.31 hour per week.

Table 3: Tobit (Marginal Effects) of Hours Spent of Children on Market Work

\begin{tabular}{|c|c|c|c|c|c|c|}
\hline \multirow[t]{2}{*}{ Explanatory Variables } & \multicolumn{3}{|c|}{ Children Aged 5-14 years } & \multicolumn{3}{|c|}{ Children Aged $15-17$ years } \\
\hline & All & Boys & Girls & All & Boys & Girls \\
\hline Girls & $\begin{array}{l}-1.1260 * \\
(0.1441)\end{array}$ & - & - & $\begin{array}{r}-1.7662 * \\
(0.5967)\end{array}$ & - & - \\
\hline Age & $\begin{array}{c}0.6266^{* *} \\
(0.2515)\end{array}$ & $\begin{array}{l}0.4653^{*} \\
(0.2981)\end{array}$ & $\begin{array}{c}0.7957^{* * *} \\
(0.4198)\end{array}$ & $\begin{array}{c}-18.1989 \\
(19.3600)\end{array}$ & $\begin{array}{l}-18.4186 \\
(28.0180)\end{array}$ & $\begin{array}{l}-12.1297 \\
(27.2420)\end{array}$ \\
\hline Age Squared & $\begin{array}{l}-0.0008 \\
(0.0121)\end{array}$ & $\begin{array}{c}0.0045 \\
(0.0143)\end{array}$ & $\begin{array}{l}-0.0065 \\
(0.0200)\end{array}$ & $\begin{array}{c}0.5732 \\
(0.6066)\end{array}$ & $\begin{array}{l}0.6147 \\
(0.8780)\end{array}$ & $\begin{array}{c}0.3476 \\
(0.8527)\end{array}$ \\
\hline Others & $\begin{array}{l}-0.2129 \\
(0.1669)\end{array}$ & $\begin{array}{l}-0.2675 \\
(0.2152)\end{array}$ & $\begin{array}{l}-0.1429 \\
(0.2537)\end{array}$ & $\begin{array}{l}-0.8816 \\
(0.7018)\end{array}$ & $\begin{array}{l}-0.6261 \\
(1.0045)\end{array}$ & $\begin{array}{l}-0.9128 \\
(0.9668)\end{array}$ \\
\hline Father-Stay & $\begin{array}{c}-0.5112 * * * \\
(0.2734)\end{array}$ & $\begin{array}{c}-0.9211^{*} \\
(0.3182)\end{array}$ & $\begin{array}{c}-0.1003^{* *} \\
(0.0477)\end{array}$ & $\begin{array}{c}-4.4995^{*} \\
(1.4835)\end{array}$ & $\begin{array}{l}-0.6145 \\
(1.9130)\end{array}$ & $\begin{array}{c}-7.7097^{*} \\
(2.1429)\end{array}$ \\
\hline Mother-Stay & $\begin{array}{c}-1.1111^{*} \\
(0.4209)\end{array}$ & $\begin{array}{l}-1.7396^{*} \\
(0.4910)\end{array}$ & $\begin{array}{l}-0.9964^{*} \\
(0.6785)\end{array}$ & $\begin{array}{c}-2.8955^{* * *} \\
(1.7278)\end{array}$ & $\begin{array}{c}-4.1390 * * * \\
(2.1986)\end{array}$ & $\begin{array}{l}-0.4691 \\
(2.6782)\end{array}$ \\
\hline $\begin{array}{l}\text { Father's Education } \\
\text { Mother's Education }\end{array}$ & $\begin{array}{l}-0.0879 * \\
(0.0256)\end{array}$ & $\begin{array}{l}-0.1209 * \\
(0.0308)\end{array}$ & $\begin{array}{l}-0.0865^{*} \\
(0.0410)\end{array}$ & $\begin{array}{c}-0.2325^{* *} \\
(0.1142)\end{array}$ & $\begin{array}{l}-0.1237 \\
(0.1545)\end{array}$ & $\begin{array}{l}-0.5259 * \\
(0.1501)\end{array}$ \\
\hline Household Income & $-0.0758^{*}$ & $-0.1245^{*}$ & $-0.1215^{*}$ & 0.1020 & 0.1550 & 0.0504 \\
\hline Piped & $(0.0279)$ & $(0.0408)$ & $(0.0407)$ & $(0.1133)$ & $(0.1408)$ & $(0.1285)$ \\
\hline & $-0.0002 * *$ & $-0.0002 * *$ & $-0.0001 * *$ & $-0.0001 * *$ & $-0.0002 *$ & 0.0001 \\
\hline Household Size & $(0.0001)$ & $(0.0001)$ & $(0.0001)$ & $(0.0001)$ & $(0.0001)$ & $(0.0001)$ \\
\hline & $-0.2990 * *$ & $-0.1899 * *$ & $-0.4548^{*}$ & 0.2526 & $-1.8423 * * *$ & -0.5651 \\
\hline Muslim & $(0.1822)$ & $(0.0230)$ & $(0.2852)$ & $(0.6955)$ & $(1.0586)$ & $(0.9194)$ \\
\hline & 0.0345 & 0.0298 & 0.0316 & 0.0009 & 0.0227 & -0.0804 \\
\hline Child (Aged below 5) & $(0.0247)$ & $(0.0298)$ & $(0.0388)$ & $(0.1116)$ & $(0.1523)$ & $(0.1630)$ \\
\hline Jawa & $-1.2033^{*}$ & $-0.9798^{*}$ & $-1.5499 *$ & 0.2836 & 0.7208 & -0.1331 \\
\hline & $(0.2515)$ & $(0.3275)$ & $(0.3865)$ & $(0.8866)$ & $(1.2668)$ & $(1.2438)$ \\
\hline Lesser Sunda Islands & 0.2018 & 0.1298 & $0.3083^{* * *}$ & 0.5729 & 0.4482 & 0.7188 \\
\hline Kalimantan & $(0.1266)$ & (0.1739) & $(0.1764)$ & $(0.6457)$ & $(0.8671)$ & $(0.9127)$ \\
\hline & $-1.0084 *$ & $-1.1695^{*}$ & $-0.7578 * *$ & $-3.6256^{*}$ & $-3.9319 *$ & $-3.3536^{*}$ \\
\hline Sulawesi & $(0.1785)$ & $(0.2129)$ & $(0.2933)$ & $(0.8079)$ & (1.1122) & $(1.1653)$ \\
\hline & -0.0407 & -0.4654 & 0.4266 & $4.0380^{*}$ & $5.3249 *$ & $2.8791^{* * *}$ \\
\hline & $(0.2265)$ & $(0.2838)$ & $(0.3603)$ & $(1.0861)$ & $(1.5030)$ & $(1.5384)$ \\
\hline & $-1.2355^{*}$ & $-1.6654^{*}$ & -0.7339 & -2.1691 & -3.2449 & -1.4127 \\
\hline & $(0.3179)$ & $(0.4043)$ & $(0.5040)$ & (1.5526) & $(2.0102)$ & $(2.4006)$ \\
\hline & $-1.0631^{*}$ & $-0.0898 * *$ & $-1.5569 *$ & -1.1086 & -1.2815 & -1.1982 \\
\hline & $(0.2928)$ & $(0.3366)$ & $(0.5407)$ & (1.2679) & $(1.9022)$ & $(1.6945)$ \\
\hline Pseudo $\mathrm{R}^{2}$ & 0.0835 & 0.0964 & 0.0782 & 0.0048 & 0.0068 & 0.0053 \\
\hline Number of & 9461 & 4843 & 4618 & 2502 & 1232 & 1270 \\
\hline $\begin{array}{l}\text { Observations } \\
\text { Log-likelihood }\end{array}$ & -3732.817 & -1952.022 & -1787.048 & -10059.276 & -5023.580 & -5002.091 \\
\hline
\end{tabular}

Notes: $*, * *, * * *$ statistically significance at $1 \%, 5 \%$ and $10 \%$.

\section{Conclusion}

The findings suggest that the difference between the average numbers of hours worked of the boys and the girls have a statistically differential effect on working and doing housework, 
especially among children aged 5-14 years, which is also support the results found by Baland \& Robinson (2000). The results show that girls aged 5-14 years are more likely to spend more hours on working and doing housework. However, for children aged 15-17 years, the results show that boys spend more time on working compared to girls.

Fathers staying at home significantly increase the hours spent on schooling. The same results are also shown by parent's years of schooling and household income for both children aged 5-14 years and 15-17 years. In particular, the effects are higher for girls compared to boys. In addition, having piped water in the household increase the hours devoted to schooling, while the presence of pre-school aged children in the household negatively relates to the hours spent on schooling. These two results are significant for children aged 5-14 years, but are insignificant for children aged 15-17 years. The effects of the variables in housework category and working category are found to be significant, mostly among girls compared to boys. For the housework category, fathers stay and mothers stay significantly increases the hours of girls on doing housework. In terms of parents' years of education, fathers' education significantly reduces the hours spent by girls on doing household chores. The similar effects are given by the household income and having piped water in the household. Both boys and girls spend fewer hours on doing housework if there is a presence of preschool aged children in the household. These effects are larger for girls compared to boys.

Children aged 5-14 years spend fewer hours on working if both parents stay at home. The effects are significant for both girls and boys. For children aged 15-17 years, fathers stay at home shows a significant effect on girl's hours of working, while mother's stay at home have a significant effect on boy's hours spent on working. Father's education seems to reduce the hours of work for both genders of children aged 5-14 years, and for girls aged 15-17 years. Increase in household income and the availability of piped water in the household also shows a significant effect for boys and girls aged 5-14 years. However, among children aged 15-17 years, the effects are significant on boys, but not for girls. These results confirm the existence of gender differences among younger children in their time allocation, and this reflects the prevalence of son preference as one of the reasons in explaining the differences.

Thus, promotion of policies such as providing opportunities and raising women's status would be a step in the right direction, especially in terms of returns to schooling and job opportunities. The condition that younger girls work more than the boys should be monitored as well, since they are still in school age, even though they only spend more time doing housework. Thus, increasing women's bargaining power may contribute the largest effect on reducing gender disparities. Undoubtedly, policies targeting gender-discriminatory attitudes by means of educational or further affirmative action policies are most desirable. The policies could help to increase the capacity of women to decide independently which in turn will lessen the influence of male dominance in household decision making.

\section{References}

Baland, J. M., \& Robinson, J. A. (2000). Is Child Labour Inefficient? The Journal of Political Economy, 108(4), 663-679.

Basilio, L. (2009). Deciding Who Works Where: An Analysis of the Distribution of Work within Native and Immigrant Families in Australia. Ruhr Economic Papers (No. 125). 
INTERNATIONAL JOURNAL OF ACADEMIC RESEARCH IN BUSINESS AND SOCIAL SCIENCES

Vol. 8, No. 12, Dec, 2018, E-ISSN: 2222-6990 @ 2018 HRMARS

Basu, K., Das, S., \& Dutta, B. (2009). Child Labour and Household Wealth: Theory and Empirical Evidence of an Inverted-U. IZA Discussion Papers (No. 2736).

Bhalotra, S., \& Heady, C. (2000). Child Farm Labour: Theory and Evidence. STICERD Development Economics Working Paper (No. 24).

Canagarajah, S. \& Coulombe, H. (1997). Child Labour and Schooling in Ghana. The World Bank Policy Research Working Paper Series (No. 1844).

Carvalho-Filho, I. (2008). Household Income as a Determinant of Child Labour and School Enrolment in Brazil: Evidence from a Social Security Reform. IMF Working Papers (N0. 08/241).

Cockburn., J. (2001). Child Labour versus Education: Poverty Constraints or Income Opportunities. Discussion Paper 01-06, Centre de Recherchers en Economie et Finances Appliquees, Laval University, Quebec.

Deolalikar, A. B. (1993). Gender Differences in the Returns to Schooling and in School Enrolment Rates in Indonesia. The Journal of Human Resources, Special Issue: Symposium on Investments in Women's Human Capital and Development, 28(4), 899- 932.

Edmonds, E. V. (2006). Child Labor and Schooling Responses to Anticipated Income in South Africa. Journal of Development Economics, 81(2), 386-414.

Fuse, K. (2010). Variations in Attitudinal Gender Preferences for Children across 50 Less-Developed Countries. Demographic Research, 23(36), 1031-1048.

Gallego, J. M., \& Sepulveda, C. E. (2007). Gender Differences on Child Labour, from www.ucwproject.org/attachment /Gallego\& Sepulveda.pdf

Grootaert, C. (1998). Child Labour in Cote d'Ivoire: Incidence and Determinants. The World Bank Working Paper (No. 1905).

Guarcello, L., Lyon, S., \& Rosati, F. C. (2004). Child Labour and Access to Basic Services: Evidence from Five Countries. Understanding Children's Work (UCW) Project Working Paper.

Hank, K., \& Kohler, H-P. (2000). Gender Preferences for Children in Europe: Empirical Results from 17 FFS Countries. Demographic Research, 2.

Horowitz, A. W., \& Wang, J. (2004). Favourite Son? Specialized Child Labourers and Students in Poor LDC Households. Journal of Development Economics, 73(2004): 631-642.

Jeong, J. (2005). The Determinants of Child Labor and Schooling in Honduras, Nicaragua, and Panama, from http://economics.stanford.edu/files/Theses/Theses_2005/Jeong.pdf

Kamga, A. K. (2010). Trade-off between Child Labor and Schooling in Urban and Rural Areas: Evidence from Cameroon, from http://www.csae.ox.ac.uk/conferences/2010EDiA/papers/397-Kamga.pdf

Kevane, M., \& Levine, D. (2003). Changing Status of Daughters in Indonesia. Working Paper Series, Institute for Research on Labour and Employment, University of California, Berkeley.

Khanam, R. (2006). Child Labour in Bangladesh: Determinants and Effects. Munich Personal RePEC Archive (MPRA) Working Paper (No. 6990).

Krolikowski, P. M. (2007). Poverty and Religion: An Investigation into Child Labour in Ghana, from http://economics. stanford.edu/files/Theses/Theses_2007/KrolikowskiThesis 2007.pdf

Koolwal, G. B. (2007). Son Preference and Child Labour in Nepal: The Household Impact of Sending Girls to Work. World Development, 35(5), 881-903. 
INTERNATIONAL JOURNAL OF ACADEMIC RESEARCH IN BUSINESS AND SOCIAL SCIENCES

Vol. 8, No. 12, Dec, 2018, E-ISSN: 2222-6990 @ 2018 HRMARS

Kumar, A. (2011). Son Preference, Gender Differentials in Child Labour and Schooling, and Efficiency, from http://www.econ.yale.edu/conference/neudc11/papers/paper252.pdf

Lin, T-C., \& Adsera, A. (2012). Son Preference and Children's Housework: The Case of India. IZA Discussion Paper (No. 6929).

Parikh, A. \& Sadoulet, E. (2005). The Effect of Parents' Occupation on Child Labor and School Attendance in Brazil, from http://are.berkeley.edu/ esadoulet/papers/ChildLabor.pdf

Priyambada, A., Suryahadi, A., \& Sumarto, S. (2005). What Happened to Child Labor in Indonesia during the Economic Crisis: The Trade-off between School and Work. East Asean Bureau of Economic Research, (No. 87).

Ray, R. \& Lancaster, F. (2003). Does Child Labour Affect School Attendance and School Performance? Multi Country Evidence on SIMPOC Data. Discussion Paper 2003-2004 School of Economics, Australia: University of Tasmania.

Rogers, C. A. \& Swinnerton, K. A. (2003). Does Child Labor Decrease When Parental Incomes Rise?. Development and Comp Systems, EconWPA.

Rosati, F. C., \& Rossi, M. (2007). Impact of School Quality on Child Labour and School Attendance: The Case of CONAFE Compensatory Education Program in Mexico. Understanding Children's Work (UCW) Project.

Togunde, D., \& Richardson, S. (2006). Household Size and Composition as Correlates of Child Labour in Urban Nigeria. Africa Development, 31(1), 50-65.

Webbink, E., Smits, J., \& De Jong, E. (2010). Hidden Child Labour: Determinants of Housework and Family Business Work of Children in 16 Developing Countries. World Development, 40(2012), 631-642. 